\title{
Correction: Do farm-grown lungs breathe better?
}

Genuneit J, von Mutius E. Do farm-grown lungs breathe better? Thorax 2017;72:202-3.

The authors include the additional Conflicts of Interest for their article:

Erika von Mutius is listed as inventor on the following patents:

- Publication number EP 1411977: Composition containing bacterial antigens used for the prophylaxis and the treatment of allergic diseases.

- Publication number EP1637147: Stable dust extract for allergy protection

- Publication number EP 1964570: Pharmaceutical compound to protect against allergies and inflammatory diseases

Erika von Mutius is listed as inventor and has received royalties on the following patent:

- Publication number EP2361632: Specific environmental bacteria for the protection from and/or the treatment of allergic, chronic inflammatory and/or autoimmune disorders.

(c) Author(s) (or their employer(s)) 2019. No commercial re-use. See rights and permissions. Published by BMJ.

Thorax 2019;74:924. doi:10.1136/thoraxjnl-2016-209280corr1

Check for updates 